diastereoselectivity (d.e. $>95 \%$ in all cases studied) to give the alkylation products 9 in which the alkyl group $R$ has entered trans with respect to the isopropyl group at C-6, i.e., $R$-configuration is induced at C-3 of 9 [with D-valine as chiral auxiliary reagent, $S$-configuration would be induced]. Acidic hydrolysis of compounds 9 affords the $(R)-\alpha$-methyl- $\alpha$-amino acid methyl esters $\mathbf{1 0}$ and $\mathrm{L}-\mathrm{Val}-\mathrm{OCH}_{3}$. Usually, these two esters can be easily separated by distillation and the chiral auxiliary component L-Val-OCH $\mathrm{H}_{3}$ thus be recovered.

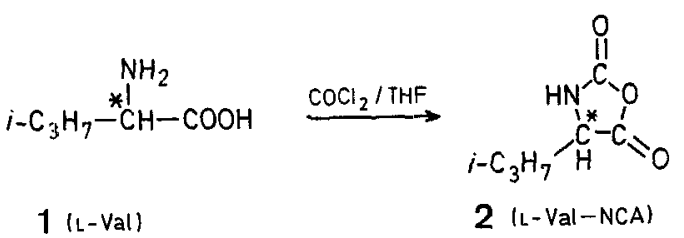

D.L $-\mathrm{Ala}-\mathrm{OCH}_{3}-\mathrm{HCl}(3) /$

$\stackrel{\left(\mathrm{C}_{2} \mathrm{H}_{5}\right)_{3} \mathrm{~N} / \mathrm{THF}^{-} \mathrm{CHCl}_{3},-70^{\circ} \mathrm{C}}{\longrightarrow}$ L-Val-D.L-Ala $-\mathrm{OCH}_{3} \stackrel{\text { toluene, } \nabla}{\longrightarrow}$
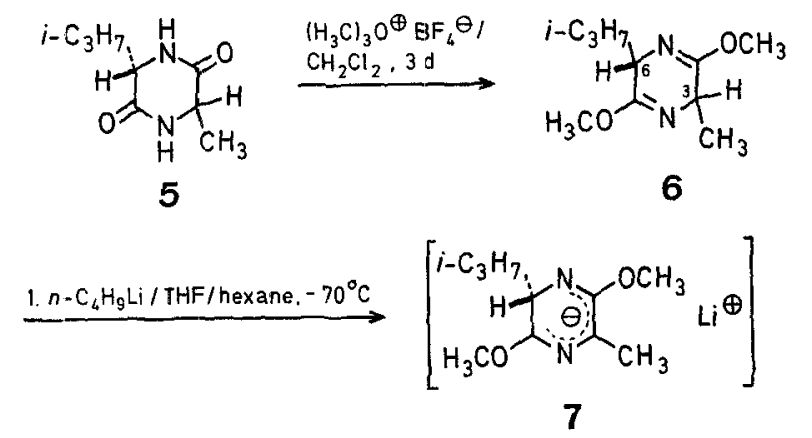

Asymmetric Syntheses via Heterocyclic Intermediates; VIII ${ }^{1}$. Enantioselective Synthesis of $(R)-\alpha$-Methyl- $\alpha$ amino Acids using L-Valine as Chiral Auxiliary Reagent

Ulrich SCHÖLlKOPF, Ulrich GROTH, Karl-Otto WESTPHALEN, Chuangzheng Deng

Organisch-Chemisches Institut der Universität Göttingen, Tammannstrasse 2, D-3400 Göttingen, Federal Republic of Germany

Optically active, non-proteinogenic amino acids deserve attention because of their documented or potential biological activity, for instance as pharmaceuticals or enzyme inhibitors.

Recently, we reported on the enantioselective synthesis of $\alpha$ methyl- $\alpha$-amino acids starting with the bis-lactim ether of cyclo(L-Ala-L-Ala) ${ }^{2}$.<smiles>COC1=NC(C)C(OC)=NC1C</smiles>

After lithiation, the lithio derivative was alkylated with alkyl halides and the alkylation product subsequently hydrolyzed to L-Ala- $\mathrm{OCH}_{3}$ and the $(R)-\alpha$-methyl- $\alpha$-amino acid methyl ester (Type 10). The diastereoselectivity of the $\mathrm{C}-\mathrm{C}$ bond-forming alkylation step is $90-95 \%$. Despite the rather high asymmetric induction, this method has the disadvantage that only half of the chiral auxiliary compound (L-Ala) is recovered; the other half is incorporated in the product. This disadvantage is avoided by using the "mixed" bis-lactim ether 6 from cyclo(LVal-Ala). Lithiation (butyllithium, THF, $-70^{\circ} \mathrm{C}$ ) occurs regiospecifically in the alanine part of the molecule. The lithio derivative 7 reacts with alkyl halides (8) in unusually high
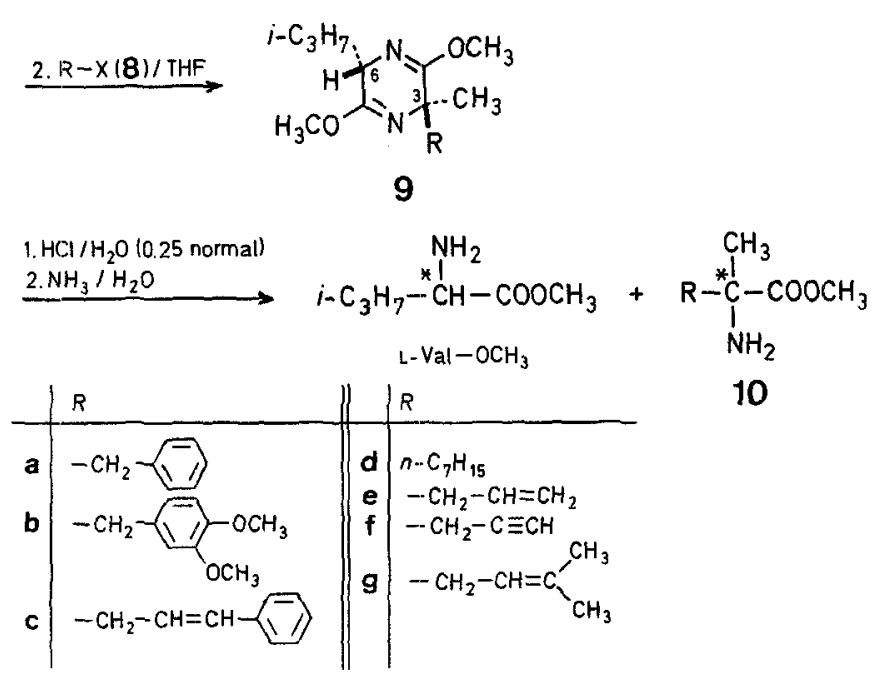

The assignment of configuration of compounds 9 is based on the ' $\mathrm{H}$ N.M.R. spectra of 9 and/or on the sign of rotation of the amino acid esters 10 formed on hydrolysis. In the case $\mathrm{R}=-\mathrm{CH}_{2}-\mathrm{Ar}$, compounds 9 adopt the "folded conformation" in which the aryl ring faces the heterocycle ${ }^{2.3}$. Hence, in the ${ }^{1}$ H-N.M.R. spectrum, the signal of $\mathbf{6}-\mathrm{H}$ experiences a characteristic upfield shift. In case of $9 \mathbf{a}, \mathbf{b}, \mathbf{c}$, we prepared the $(6 S, 3 S)$-diastereoisomers for comparison by reversing the sequence of group introduction at $\mathbf{C}-3$, starting with the bis-lactim ethers $11 \mathbf{a}, \mathbf{b}, \mathbf{c}$ and introducing the methyl group with methyl iodide or dimethyl sulfate (d.e.: 9a, $\sim 85 \% ; 9 \mathrm{~b}, \sim 81 \% ; 9 \mathrm{c}, \sim 85 \%$ ). For $9 \mathrm{~d}-\mathrm{g}$, the $(3 R)$-configuration is assumed by analogy.<smiles>[R]C1C([2H])=N[C@@H](OC)[C@@H]([13CH2][2H])N=C1OC</smiles> 
To explain the unusually high induction of the alkylation step $7 \rightarrow 9$, we postulate the planar conformation $A^{5}$ for the anion of 7 which is attacked by the electrophile 8 predominantly from the less shielded top side.

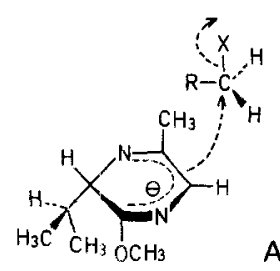

The bis-lactim ether 6 is prepared as follous. L-Valine (1) is converted with phosgene into L-Val-NCA (2). This compound is condensed with D, L-Ala- $\mathrm{OCH}_{3}$ to give the dipeptide. 1-Val-D,L-Ala-OCH 3 which cyclizes on heating to cyclo(L-Val-Ala) (5). This is transformed to the bis-lactim ether 6 with trimethyloxonium tetrafluoroborate ${ }^{5}$.

\section{L-Valine $\mathrm{N}$-Carboxyanhydride (L-Val-NCA, 2):}

Into a stirred suspension of L-valine $(1: 46.8 \mathrm{~g}, 0.4 \mathrm{~mol})$ in dry tetrahy. drofuran $(600 \mathrm{ml})$, a stream of phosgene is introduced ( $~ 30 \mathrm{~min})$ until 1 has completely dissolved. Then, nitrogen is bubbled through the mixture to remove excess phosgene and the solvent is distilled off in vacuo (after another distillation it can be used again). The residual crude product 2 is dissolved in tetrahydrofuran $(100 \mathrm{ml})$ and this sol* vent is evaporated again to remove hydrogen chloride. The residual still crude product 2 (yield almost quantitative) is dried at $40^{\circ} \mathrm{C} / 14$ torr and used in the next step without further purification.

\section{Cyclo(L-Val-Ala) (5):}

A solution of crude L-Val-NCA ( $2 ; 58 \mathrm{~g}, 0.4 \mathrm{~mol})$ in dry tetrahydrofuran $(400 \mathrm{ml})$ is added dropwise to a stirred solution of D, L-alanine methyl ester hydrochloride $(3 ; 55.8 \mathrm{~g}, 0.4 \mathrm{~mol})$ and triethylamine $(90.9 \mathrm{~g}$ $0.9 \mathrm{~mol}$ ) in chloroform $(500 \mathrm{ml})$ at $-60^{\circ}$ to $-70^{\circ} \mathrm{C}$, and stirring is continued for $3 \mathrm{~h}$ at $-70^{\circ} \mathrm{C}$ and for $30 \mathrm{~min}$ at room temperature. Then, triethylamine hydrochloride is filtered off and the filtrate evaporated to dryness in vacuo $\left(40^{\circ} \mathrm{C}\right)$. The crude L-Val-D,L-Ala-OCH $(4)$ thus obtained is dissolved in toluene $(1700 \mathrm{ml})$, the solution stirred and refluxed for $12 \mathrm{~h}$, and cooled to $0^{\circ} \mathrm{C}$. The precipitated product 5 is isolated by suction, washed (on the filter) several times with cold ether, and dried in vacuo at $100^{\circ} \mathrm{C}$ for $\sim 3$ days; yield: $58 \mathrm{~g}(85 \%)$. The product is used in the next step without further purification.

\section{(3S,6S,R)-2,5-Dimethoxy-3-isopropyl-6-methyl-3,6-dihydropyrazine} (Bis-lactim Ether 6):

A suspension of cyclo(L-Val-Ala) $(5 ; 8.5 \mathrm{~g}, 50 \mathrm{mmol})$ and trimethyloxonium tetrafluoroborate $(18.5 \mathrm{~g}, 125 \mathrm{mmol})$ in dichloromethane (200) $\mathrm{ml}$ ) is vigorously stirred for 3 days [after $24 \mathrm{~h}$, additional trimethyloxonium tetrafluoroborate $(7.4 \mathrm{~g}, 50 \mathrm{mmol})$ is added]. To the resultant mixture, $\&$ solution of sodium dihydrogen phosphate $\left(\mathrm{NaH}_{2} \mathrm{PO}_{4} \cdot 2 \mathrm{H}_{2} \mathrm{O} ; 28.1 \mathrm{~g}\right)$ and disodium hydrogen phosphate $\left(\mathrm{Na}_{2} \mathrm{HPO}_{4} \cdot 2 \mathrm{H}_{2} \mathrm{O} ; 106 \mathrm{~g}\right)$ in water $(500 \mathrm{ml})$ is added. The layers are separated and the aqueous layer is extracted with dichloromethane $(3 \times 50 \mathrm{ml})$. The combined organic layers are dried with magnesium sulfate, the solvent is evaporated, and the residual product 6 purified by distillation in vacuo; yield: $8.8 \mathrm{~g}(89 \%)$; b.p. $83-85^{\circ} \mathrm{C} / 8-10$ torr; $[\alpha]_{1)}^{20 \prime}:+82.0^{\circ}$ (c 1.0, ethanol).

$\begin{array}{llrr}\mathrm{C}_{10} \mathrm{H}_{38} \mathrm{~N}_{2} \mathrm{O}_{2} & \text { calc. } & \mathrm{C} 60.58 & \mathrm{H} 9.15 \\ (198.3) & \text { found } & 60.69 & 9.17\end{array}$

I.R. (film): $v=1685 \mathrm{~cm}^{-1}(\mathrm{C}=\mathrm{N})$.

${ }^{1}$ H-N.M.R. $\left(\mathrm{CDCl}_{3} / \mathrm{TMS}\right): \delta=1.41,1.42 \mathrm{ppm}\left(\mathrm{d}, 3 \mathrm{H}, J=3 \mathrm{~Hz}, 3 \cdot \mathrm{CH}_{3}\right.$, trans/cis-6).

3-Substituted (3R,6S)-2,5-Dimethoxy-3-isopropyl-6-methyl-3,6-dihydropyrazines (9); General Procedure:

To a stirred solution of compound $6(0.6 \mathrm{~g}, 3 \mathrm{mmol})$ in dry tetrahydrofuran $(7 \mathrm{ml})$ at $-70^{\circ} \mathrm{C}$, a 1.55 normal solution $(2.1 \mathrm{ml}, 3.3 \mathrm{mmol})$ of butyllithium in hexane is added by syringe and stirring is continued for $15 \mathrm{~min}$. Then, a precooled solution of the alkyl halide $8(3.3 \mathrm{mmol})$ in dry tetrahydrofuran $(7 \mathrm{ml})$ is added and stirring is continued for 8 $24 \mathrm{~h}$ at $-70^{\circ} \mathrm{C}$. The cooling bath is removed, the solvent evaporated in vacuo, and the residue dissolved in a small amount of ether. The ether solution is shaken with water $(10 \mathrm{ml})$, the water layer is extracted with ether $(2 \times 5 \mathrm{ml})$, and the combined ether phases are dried with magnesium sulfate. The solvent is evaporated in vacuo and the residual crude product 9 purified by bulb-to-bulb distillation. The diastereoisomeric ezcess (d.e.) of products 9 thus obtained may be assumed to be $>95 \%$ if only one signal of the $3-\mathrm{CH}_{3}$ group is observed in the 'H-N.M.R. spectrum.

I.R. (film): $v=1680-1690 \mathrm{~cm}^{-1}(\mathrm{C}=\mathrm{N})$.

Table 1. 3-Substituted (3R,6S)-2,5-Dimethoxy-3-isopropyl-6-methyl-3,6-dihydropyrazines (9) and (3S,6S)-Analogs

\begin{tabular}{|c|c|c|c|c|c|c|c|c|}
\hline Product & Educt & $\begin{array}{l}X \text { in } \mathrm{R}-\mathrm{X}(\mathrm{8}) \\
\text { [or methylating } \\
\text { agent] }\end{array}$ & $\begin{array}{l}\text { Reaction } \\
\text { time [h] }\end{array}$ & $\begin{array}{l}\text { Yield } \\
{[\%]}\end{array}$ & $\begin{array}{l}\text { d.e. } \\
{[\%]}\end{array}$ & $\begin{array}{l}\text { b.p./torr: } \\
{[\mathrm{Cl}}\end{array}$ & $\begin{array}{l}\text { Molecular } \\
\text { formula }^{h}\end{array}$ & $\begin{array}{l}\left.\text { 'H-N.M.R. (CDCl }{ }_{3} / \mathrm{TMS}\right) \\
\delta \text { [ppm] }\end{array}$ \\
\hline$(3 R, 6 S)-9 \mathrm{a}$ & 6 & $\mathrm{Br}$ & 12 & 68 & $>>95$ & $\begin{array}{l}100-110^{\circ} \\
0.1\end{array}$ & $\begin{array}{l}\mathrm{C}_{17} \mathrm{H}_{24} \mathrm{~N}_{2} \mathrm{O}_{2} \\
(288.4)\end{array}$ & $1.50\left(\mathrm{~s}, 3-\mathrm{CH}_{3}\right) ; 3.18(\mathrm{~d}, J=3 \mathrm{~Hz}, 6-\mathrm{H})$ \\
\hline$(3 S, 6 S)-9 a$ & $11 \mathbf{a}$ & {$\left[\mathrm{CH}_{3} \mathrm{~J}\right]$} & 14 & 82 & $\sim 85$ & & & $1.45\left(\mathrm{~s}, 3-\mathrm{CH}_{3}\right) ; 3.78(\mathrm{~d}, J=4 \mathrm{~Hz}, 6-\mathrm{H})$ \\
\hline$(3 R, 6 S)-9 \mathrm{~b}$ & 6 & $\mathrm{Br}$ & 12 & 76 & $>95$ & $\begin{array}{l}130-140^{\circ} \% \\
0.01\end{array}$ & $\begin{array}{l}\mathrm{C}_{19} \mathrm{H}_{28} \mathrm{~N}_{2} \mathrm{O}_{4} \\
(348.5)\end{array}$ & $1.48\left(\mathrm{~s}, 3-\mathrm{CH}_{3}\right) ; 3.28(\mathrm{~d}, J=3 \mathrm{~Hz}, 6-\mathrm{H})$ \\
\hline$(3 S, 6 S)-9 b$ & $11 \mathrm{~b}$ & $\begin{array}{l}{\left[\mathrm{CH}_{3} \text { or }\right.} \\
\left(\mathrm{H}_{3} \mathrm{CO}_{2} \mathrm{SO}_{2}\right]\end{array}$ & 14 & 74 & $\sim 80$ & & & $1.42\left(\mathrm{~s}, 3-\mathrm{CH}_{3}\right) ; 3.92\left(\mathrm{~d}_{3} J=4 \mathrm{~Hz}, 6-\mathrm{H}\right)$ \\
\hline$(3 R, 6 S)-9 \mathrm{c}$ & 6 & $\mathrm{Br}$ & 8 & 80 & $>95$ & $\begin{array}{l}110-120^{\circ} \\
0.01\end{array}$ & $\begin{array}{l}\mathrm{C}_{19} \mathrm{H}_{26} \mathrm{~N}_{2} \mathrm{O}_{2} \\
(314.4)\end{array}$ & $1.41\left(\mathrm{~s}, 3-\mathrm{CH}_{3}\right) ; 3.87(\mathrm{~d}, J=4 \mathrm{~Hz}, 6-\mathrm{H})$ \\
\hline$(3 S, 6 S)-9 c$ & $11 \mathrm{c}$ & {$\left[\mathrm{CH}_{3} \mathbf{J}\right]$} & 14 & 89 & -85 & & & $1.36\left(\mathrm{~s}, 3-\mathrm{CH}_{3}\right) ; 3.91(\mathrm{~d}, J=3 \mathrm{~Hz}, 6-\mathrm{H})$ \\
\hline$(3 R, 6 S)-9 \mathrm{~d}$ & 6 & $\mathrm{Br}$ & 24 & 43 & $>95$ & $\begin{array}{l}110-120^{\circ} \% \\
0.01\end{array}$ & $\begin{array}{l}\mathrm{C}_{17} \mathrm{H}_{32} \mathrm{~N}_{2} \mathrm{O}_{2} \\
(296.5)\end{array}$ & $1.36\left(\mathrm{~s}, 3-\mathrm{CH}_{3}\right) ; 3.97(\mathrm{~d}, J=3 \mathrm{~Hz}, 6-\mathrm{H})$ \\
\hline$(3 R, 6 S) \cdot 9 \mathrm{e}$ & 6 & $\mathrm{Br}$ & 12 & 90 & $>95$ & $\begin{array}{l}100-110^{\circ} / \\
10\end{array}$ & $\begin{array}{l}\mathrm{C}_{13} \mathrm{H}_{22} \mathrm{~N}_{2} \mathrm{O}_{2} \\
(238.3)\end{array}$ & $1.36\left(\mathrm{~s}, 3-\mathrm{CH}_{3}\right) ; 3.90(\mathrm{~d}, J=3 \mathrm{~Hz}, 6-\mathrm{H})$ \\
\hline$(3 R, 6 S)-9 f$ & 6 & $\mathrm{Br}$ & 8 & 81 & $>95$ & $\begin{array}{l}120-120 \% \\
10\end{array}$ & $\begin{array}{l}\mathrm{C}_{10} \mathrm{H}_{20} \mathrm{~N}_{2} \mathrm{O}_{2} \\
(236.3)\end{array}$ & $1.38\left(\mathrm{~s}, 3-\mathrm{CH}_{3}\right) ; 4.05(\mathrm{~d}, J=3 \mathrm{~Hz}, 6-\mathrm{H})$ \\
\hline$(3 R, 6 S)-9 \mathrm{~g}$ & 6 & $\mathrm{Br}$ & 10 & 94 & $>95$ & $\begin{array}{l}80-90^{\circ} \\
0.1\end{array}$ & $\begin{array}{l}\mathrm{C}_{15} \mathrm{H}_{26} \mathrm{~N}_{2} \mathrm{O}_{2} \\
(266.4)\end{array}$ & $1.30\left(\mathrm{~s}, 3-\mathrm{CH}_{3}\right) ; 3.87(\mathrm{~d}, J=3 \mathrm{~Hz}, 6-\mathrm{H})$ \\
\hline
\end{tabular}

\footnotetext{
Temperature of bulb-to-bulb distillation.
}

n The microanalyses were in satisfactory agreement with the calculated values: $\mathrm{C}, \pm 0.37 ; \mathrm{H}, \pm 0.22$. Exceptions were $(3 R, 6 S)-9 \mathrm{a}(\mathrm{C},+0.65)$ and $(3 R, 6,5)-9 \mathrm{~d}(\mathrm{C},-0.53)$ 
Table 2. $\alpha$-Methyl- $\alpha$-amino Acid Methyl Esters (10)

\begin{tabular}{|c|c|c|c|c|c|c|c|}
\hline 10 & $\begin{array}{l}\text { Yield } \\
[\%]]\end{array}$ & $\begin{array}{l}\text { b.p. } / \text { torrit } \\
{\left[{ }^{\circ} \mathrm{C}\right]}\end{array}$ & {$[\alpha]_{1}^{2 n}(c$, ethanol $)$} & $\begin{array}{l}\text { e.e. } \\
{[\%]}\end{array}$ & $\begin{array}{l}\text { Molecular } \\
\text { formula }\end{array}$ & $\begin{array}{l}\text { I.R. (film) } \\
v_{\mathrm{c}=\mathrm{O}}\left[\mathrm{cm}^{-1}\right]\end{array}$ & $\begin{array}{l}\text { 'H-N.M.R. } \\
\left(\mathrm{CDCl}_{3} / \mathrm{TMS}\right)^{\mathrm{c}} \\
\delta \text { [ppm] }\end{array}$ \\
\hline$(R)-10 \mathrm{a}$ & 79 & $75-80^{\circ} / 0.05$ & $-2.8^{\circ}(c 1.0$ ethanol $)$ & $>95$ & d & & \\
\hline$(R)-10 \mathrm{~b}$ & 76 & $130-140^{\circ} / 0.1$ & $-0.7^{\circ}(c 1.1$ ethanol $)$ & $>95$ & d & & \\
\hline$(R)-10 \mathrm{c}$ & 69 & $110-120^{\circ} / 0.1$ & $-13.2^{\circ}$ (c 1.1 ethanol) & $>95$ & $\mathrm{C}_{13} \mathrm{H}_{17} \mathrm{NO}_{2}$ (219.3) & 1720 & $1.40\left(\mathrm{~s}, \mathrm{CH}_{3}\right)$ \\
\hline$(S)-10 \mathrm{c}^{\mathrm{e}}$ & 76 & $120-130 \% / 0.1$ & $+10.6^{\circ}$ (c 0.8 ethanol) & $\sim 85$ & & & $1.40\left(\mathrm{~s}, \mathrm{CH}_{3}\right)$ \\
\hline$(R)-10 \mathrm{~d}$ & $47^{\prime}$ & $90-100^{\circ} / 0.1$ & $-12.9^{\circ}$ (c 0.6 ethanol) & $>95$ & $\mathrm{C}_{11} \mathrm{H}_{23} \mathrm{NO}_{2}(201.3)$ & 1730 & $1.36\left(\mathrm{~s}, \mathrm{CH}_{3}\right)$ \\
\hline$(R)-10 \mathrm{e}$ & $90^{\mathrm{E}}$ & & $+2.33^{\circ}$ (c 0.4 ethanol $)$ & $>95$ & $\mathrm{C}_{7} \mathrm{H}_{13} \mathrm{NO}_{2}(143.2)$ & 1735 & $1.36\left(\mathrm{~s}, \mathrm{CH}_{3}\right)$ \\
\hline$(R)-10 \mathrm{f}$ & $87^{\mathrm{h}}$ & & $+2.08^{\circ}$ (c 0.8 ethanol) & $>95$ & $\mathrm{C}_{7} \mathrm{H}_{11} \mathrm{NO}_{2}(141.2)$ & 1735 & $1.39\left(\mathrm{~s}, \mathrm{CH}_{3}\right)$ \\
\hline$(R) \cdot 10 \mathrm{~g}$ & 82 & $100-110^{\circ} / 10$ & $-17.9^{\circ}$ (c 1.0 ethanol $)$ & $94^{\mathrm{i}}$ & $\mathrm{C}_{9} \mathrm{H}_{17} \mathrm{NO}_{2}(171.2)$ & 1735 & $1.33\left(\mathrm{~s}, \mathrm{CH}_{3}\right)$ \\
\hline
\end{tabular}

"Temperature of bulb-to-bulb distillation.

b The microanalyses were in satisfactory agreement with the calculated values: $\mathrm{C}, \pm 0.37 ; \mathrm{H}, \pm 0.22$.

- Using $\operatorname{Eu}(\mathrm{hfc})_{3}$ as shift reagent.

"Identified by comparison of the I.R. and 'H-N.M.R. spectra with those of authentic samples?

- Prepared from $(3 S, 6 S)-9 \mathrm{c}$.

1 Time required for hydrolysis: 8 days (shaking). $44 \%$ of $9 \mathrm{~d}$ could be recovered from the ether extract of the acidic aqueous mixture.

1:1 Mixture of 10e and L-Val- $\mathrm{OCH}_{3}$. Product 10e was isolated by G.L.C. (Chromosorb W, 60/80 mesh, 15\% OV 210).

"Mixture of $10 \mathrm{f}$ and L-Val- $\mathrm{OCH}_{3}$. Product $10 \mathrm{f}$ was isolated by G.L.C.

' Lower limit. An impurity may possibly mistaken for the (S)-enantiomer.

(R)- $a$-Methyl- $\alpha$-amino Acid Methyl Esters (10) from Hydrolysis of Compounds 9; General Procedure:

A suspension of the compound $9(2 \mathrm{mmol})$ in 0.25 normal hydrochloric acid $(16 \mathrm{ml}, 4 \mathrm{mmol})$ is stirred at room temperature for 3 days during which time ether ( $2-3 \mathrm{ml}$ each) is added after $24 \mathrm{~h}$ and after 48 h. The solution is extracted with ether $(2 \times 10 \mathrm{ml})$ to remove unreacted 9 and is then evaporated to dryness. The residue $(10 \cdot \mathrm{HCl}$ and $\mathrm{L}-\mathrm{Val}-$ $\left.\mathrm{OCH}_{3} \cdot \mathrm{HCl}\right)$ is dissolved in the minimum amount of water, ether $(\sim 20$ $\mathrm{ml}$ ) is added, and then concentrated aqueous ammonia is added with shaking to adjust the mixture to $\mathrm{pH} \mathrm{8-10.} \mathrm{The} \mathrm{ether} \mathrm{layer} \mathrm{is} \mathrm{separated}$ and the aqueous layer extracted with ether $(2 \times 10 \mathrm{ml})$. The combined ether layers are dried with magnesium sulfate, the solvent is evaporated in vacuo, and the residual mixture of 10 and $\mathrm{L}-\mathrm{Val}-\mathrm{OCH}_{3}$ bulbto-bulb distilled whereby $\mathrm{L}-\mathrm{Val}-\mathrm{OCH}_{3}$ is obtained as the forerun.

Received: May 5, 1981

\footnotetext{
' For Part VII, see: U. Schöllkopf, W. Hartwig, K.-H. Pospischil, H. Kehne, Synthesis 1981, 966.

2 U. Schöllkopf, W. Hartwig, U. Groth, Angew. Chem. 91, 922 (1979); Angew. Chem. Int. Ed. Engl. 18, 863 (1979).

U. Schöllkopf, W. Hartwig, U. Groth, K. O. Westphalen, Justus Liebigs Ann. Chem. 1981, 696.

3 For "folded conformations" in other benzyl-substituted heterocycles, cf. A. K. Bose et al., Heterocycles 7, 1227 (1977).

${ }^{4}$ For a discussion, see: U. Groth, Dissertation, Universität Göttingen, 1981; details to be published in different context.

5 Trimethyloxonium tetrafluoroborate was used instead of the cheaper and more reactive triethyl analog (cf. Ref. ${ }^{1.2}$ ) because the 'H-N.M.R. spectra of the resultant methyl derivatives are simpler than those of the ethyl derivatives (cf. Ref. ${ }^{3}$ ). Commercial reagents should be cleaned before use.
} 